\title{
HUBUNGAN DISTRES DAN KADAR KORTISOL DENGAN KEJADIAN OLIGO-AMENOREA PADA NARAPIDANA DI LEMBAGA PEMASYARAKATAN WANITA SESUMATERA BARAT
}

\author{
Yaslinda Yaunin ${ }^{1}$, Elita G. Ardi, Putri S. Lasmini ${ }^{2}$ Erkadius $^{3}$ \\ 1. Bagian Psikiatri Fakultas Kedokteran Universitas Andalas \\ 2. Bagian Obstetri \& Ginekologi Fakultas Kedokteran Universitas Andalas \\ 3. Bagian Fisiologi Fakultas Kedokteran Universitas Andalas \\ E-mail : linda_yns@yahoo.co.id
}

\begin{abstract}
Abstrak
Beberapa penelitian membuktikan bahwa wanita lebih banyak mengalami depresi dari pada pria. Stresor sebagai penyebab distres bisa datang sendiri-sendiri atau bersamaan. Sebagai respon terhadap distres beberapa hormon dan neurotransmitter dikeluarkan untuk mempersiapkan tubuh menahan stresor. Hiperaktivasi HPA-aksis menyebabkan korteks adrenal mengsekresi kortisol secara berlebihan ke dalam darah, juga menyebabkan pelepasan $\beta$-endorphin yang berlebihan sehingga terjadi penekanan GnRH dan menghambat LH sehingga terjadi oligomenorea dan amenorea. Penelitian ini bersifat deskriptif analitik,dengan subjek narapidana wanita di LP wanita se-Sumatera Barat pada bulan Juni 2007 s/d Desember 2007. Kriteria Inklusi : wanita usia 20-40 tahun, tidak sedang menderita penyakit sistemik, haid teratur sebelum masuk penjara, mempuyai BMI normal, bersedia ikut penelitian. Depresi ditegakkan berdasarkan PPDGJ III, sedangkan kortisol diperiksa melalui darah yang diambil melalui vena mediana cubiti pagi dan sore hari melalui pemeriksaan dengan sistem ECLIA. Hasil penelitian menunjukan kadar kortisol pagi hari pada subjek yang mengalami depresi memiliki perbedaan yang bermakna dibanding subjek yang tidak depresi, kadar kortisol sore hari tidak ada perbedaan bermakana antara subjek yang mengalami depresi dibanding tidak depresi. Tidak ada perbedaan kortisol pagi hari pada subjek yang menngalami gangguan haid dengan subjek yang haidnya normal,juga tidak terdapat hubungan yang bermakna antara gangguan haid yang terjadi dengan depresi yang dialami subjek pada penelitian ini $(\mathrm{P}=0,209)$.

Kata Kunci : Depresi, Kortisol, Oligo-amenorea
\end{abstract}

\section{Abstract}

Some studies showed that women more have depression than men.In order as the respon to stressor body will scret some hormones and some neurotransmitters. Hiperactivation of HPA-axis induce adrenal cortex to secretion more cortisol to blood stream and also more $\beta$ endhorphin that will be pressure GnRH \& inhibit LH and the end by oligomenorrhea and amenorrhea. The design of this study is analytic-descriptive studies with subjects prisoner women in West 
Sumatera,age 20-40, no physical illnes, has normal menstruation before in the prison and BMI normal range. The result showed that cortisol level in the morning is significantly different between depression and non depression subjects. There are no different cortisol level in the afternoon between depression and non depression subjects, and also no different cortisol level women with disregulation menstruation and women with normal menstruation. There are no relationship between disregulation menstruation and depression.

Key word : Depression, Cortisol, Oligomenorrhea 


\section{Pendahuluan}

Gangguan Suasana Alam

Perasaan (Gangguan Mood/Gangguan Afektif) adalah sekelompok gambaran klinik yang ditandai oleh hilangnya/berkurangnya control emosi dan pengalaman-pengalaman subjektif yang bisa dialami oleh setiap orang. Gangguan depresi adalah salah satu bentuk gangguan suasana perasaan yang bisa ditegakkan apabila sudah berlangsung lebih dari 2 (dua) minggu dan ditandai dengan paling sedikit 4 (empat) dari gejala - gejala utama yaitu : perubahan dalam nafsu makan dan berat badan, perubahan tidur dan aktifitas, kehilangan energi, rasa bersalah, gangguan dalam konsetrasi dan mengambil keputusan, dan adanya fikiran yang berlang-ulang tentang kematian dan ideide bunuh diri. ${ }^{(1)}$ Pada wanita yang sedang menjalani masa tahanan dipenjara, terpisah dari kehidupan normal, jiwanya tertekan karena perubahan lingkungan yang dialaminya, seperti halnya wanita di kamp-kamp konsentrasi. ${ }^{(2,3)}$ Beberapa penelitian epidemiologi yang cukup luas telah membuktikan bahwa wanita lebih banyak mengalami depresi dibanding pria. Peningkatan prevalensi depresi pada wanita dimulai pada usia remaja. Walaupun faktor-faktor stressor psikososial dari luar sama-sama mempengaruhi resiko terjadinya depresi pada wanita dan pria, tapi wanita lebih banyak menjadi depresi karena kesulitan hubungan interpersonal dalam lingkungan keluarga dekatnya, sedangkan pada pria tampaknya lebih dipengaruhi oleh faktor pekerjaan. ${ }^{(4)}$

Stressor adalah variabel yang dapat diidentifikasi sebagai penyebab orang mengalami distres, datangnya stressor dapat sendiri-sendiri atau dapat pula bersamaan. Stressor terdiri dari rangsangan positif (eustres) dan negatif (distres). Suatu stres menjadi patologis apabila stres tersebut melebihi kemam- puan individu untuk mengatasinya. Stres patologis mencakup infeksi, trauma, penyakit, atau tekanan mentalemosional yang ditimbulkan dari keinginan-keinginan yang tidak tercapai dalam kehidupan atau tuntutan akan suatu perubahan yang membuat individu harus beradaptasi. Stressor yang bekepanjangan merupakan tantangan bagi kemampuan untuk mempertahankan homeostasis fisik dan emosi. ${ }^{(5)}$

Sebagai respon terhadap distres beberapa hormon dan neurotransmitter dikeluarkan oleh tubuh. Hormonhormon ini mempersiapkan tubuh untuk menahan stressor dan penting untuk pertahanan mental dan fisik, ${ }^{(6)}$ Kelenjar Adrenal, yang menyebabkan hipotalamus menghasilkan dan melepaskan CRH kedalam sistem aliran darah portal hipotalamus-hipofisis, CRH menyebabkan hipofisis anterior mengeluarkan ACTH. Hormon ini beredar kedalam korteks adrenal menyebabkan pelepasan hormon glukokortikoid yaitu kortisol, sehingga terjadi sekresi kortisol yang berlebihan dari kelenjar adrenal. Dalam beberapa menit seluruh rangkaian pengaturan mengarah kepada peningkatan sekresi kortisol didalam darah dan dapat meningkat sampai 20 kali lipat. ${ }^{(7,8)}$ Pada wanita yang mengalami distress terjadi peningkatan aktifitas aksis hipotalamus - hipofisis/pituitary adrenal (HPA-Aksis), ini bisa dibuktikan dengan pemerikasaan : pelepasan kortisol bebas melalui urin, pemeriksaan kadar kortisol plasma, kadar kortisol dalam air ludah dan Dexamethason Suppression Test. ${ }^{(1)}$ Young EA dan Veldhuis JD, 2006, dalam penelitiannya menemukan terjadinya peningkatan ACTH dan kortisol pada wanita depresi disbandingkan wanita normal. ${ }^{(9)}$

Strickland dkk, 2002, menyatakan suatu hipotesis bahwa kortisol adalah suatu rantai biologis antara stres 
kehidupan dengan onset terjadinya depresi. Pada penelitian yang mengambil sampel dari populasi yang besar didapatkan hasil kortisol tidak meningkat pada keadaan awal depresi atau kondisi jiwa yang mudah jatuh ke depresi, tetapi meningkat setelah terjadi suatu stresor dalam kehidupan dan ternyata memang ada bukti poros HPA sensitif terhadap stres psikososial. ${ }^{(10)}$

Banyak faktor yang mempengaruhi haid, baik faktor internal maupun eksternal tubuh. Sejak dahulu diketahui bahwa faktor mental-emosional sangat erat hubungannya dengan terjadinya gangguan haid, baik jumlah, ritme maupun lamanya haid. Faktor-faktor psikologi mempengaruhi sekresi endokrin tubuh untuk kebutuhan penyesuaian diri terhadap perubahan lingkungan yang dihadapi seseorang. ${ }^{(11)}$

Aktivasi aksis hipotalamushipofisis-adrenal (HPA-aksis) dan penghambatan aksis HipotalamusHipofisis-Gonad (HPG) oleh stres memicu hiperaktivasi dari aksis CRH ACTH-adrenal, yang menyebabkan hipotalamus menghasilkan dan melepaskan CRH kedalam sistem aliran darah portal hipotalamus-hipofisis, $\mathrm{CRH}$ selanjutnya menekan sekresi GnRH secara langsung - CRH juga secara tidak langsung menekan $\mathrm{GnRH}$ dengan merangsang hipofisis anterior mengeluarkan hormon adrenokortikotropin (ACTH) yang di korteks adrenal, menyebabkan pelepasan hormon glukokortikoid yaitu kortisol, yang berlebihan dari kelenjar adrenal. CRH juga merangsang peningkatan pelepasan $\beta$ endorphin yang merupakan inhibitor sekresi Gonadotropin-Releasing Hormone $(\mathrm{GnRH})$. Akibat peningkatan kortisol dan $\beta$ endorphin, terjadi penekanan pada neuron GnRH dan meng- hambat pelepasan Luteinizing Hormone (LH), terjadi oligomenorea dan amenorea. ${ }^{(6-8)}$

Amenorea adalah tidak terjadinya haid pada seorang wanita. Secara umum dibedakan antara amenorea fisiologik seperti keadaan prapubertas, hamil, menyusui dan pasca menopause, serta amenorea patologik seperti pada amenorea primer dan amenorea sekunder. ${ }^{(12)}$

- Amenorea primer

Adalah belum datangnya haid pada seorang wanita yang berumur 16 tahun dan telah terlihat pertumbuhan seksual sekunder atau belum datangnya haid pada wanita yang berumur 14 tahun dan pertumbuhan seksual sekunder belum juga muncul. Penyebab dari amenorea primer harus dievaluasi dalam konteks ada atau tidaknya karakteristik seksual sekunder. ${ }^{(13)}$

- Amenorea sekunder/functional hypothalamic amenorrhea

Adalah tidak adanya menstruasi selama tiga bulan berturut-turut pada wanita yang sebelumnya mengalami menstruasi yang normal tanpa kelainan anatomi atau organik. ${ }^{(13)}$ Amenorea sekunder dibedakan atas 2 penyebabnya, yaitu : (1) amenorea yang diinduksi oleh stres (stress induced amenorrhea), (2) amenorea yang diinduksi oleh latihan fisik yang lama, penurunan berat badan, anoreksia nervosa (non stress induced amenorrhea). ${ }^{(5)}$

\section{METODE PENELITIAN}

Penelitian ini bersifat deskriptif analitik dengan total sampling. Subyek penelitian adalah semua narapidana wanita yang menjalani hukuman di Lembaga Pemasyarakatan wanita seSumatera Barat yang memenuhi kriteria 
penelitian dan pemeriksaan spesimen heparin. Pemeriksaan kadar kortisol dilakukan di Laboratorium Patologi melalui serum dengan alat Elecsys Klinik RS Dr, M, Djamil Padang mulai Cortisol reagen Kit dengan memakai pada bulan Juni 2007 sampai Desember system pemeriksaan Electro Chemilu2007, dengan kriteria inklusi : wanita minescence Immunoassay (ECLIA) usia 20-40 tahun, tidak menderita pada alat Roche Elecsys 1010/2010 dan penyakit sistemik, haid teratur sebelum modular analitycs E 170. masuk penjara, mempunyai Body Mass Index (BMI) Normal, bersedia ikut dalam penelitian. Kriteria Eksklusi adalah : sedang mendapatkan terapi hormonal atau pil KB 3 bulan terakhir, post operasi pengangkatan ovarium atau uterus, mendapat pengobatan sitostatika dan radioterapi 3 bulan, menggunakan obat psikotropika, merokok, pecandu/peminum alkohol. Variabel bebas : distress, variabel tergantung : oligoamenorea dan kortisol.

Kriteria Depresi ditentukan berdasarkan Pedoman Diagnostik Gangguan Afektif Episode Depresi menurut Pedoman Penggolongan diagnosis Gangguan Jiwa di Indonesia III. Pengambilan sampel darah melalui vena mediana cubiti sebelum makan pada pagi hari jam 08.00 WIB dan sore hari jam 18.00 WIB sebanyak $5 \mathrm{ml}$ dimasukkan dalam tabung steril yang berisis

\section{HASIL PENELITIAN}

Di Lembaga Pemasyarakatan (LP) se-Sumatera Barat ditemukan sebanyak 53 orang narapidana wanita, dengan 25 orang tersangkut dengan masalah narkotika dan bahan adiktif. Dari sisanya, sebanyak 3 orang memiliki usia di atas 40 tahun sehingga hanya 25 orang yang dapat dijadikan subjek penelitian. Sebanyak 12 orang dari subjek yng diteliti memenuhi kriteria Gangguan Depresi menurut Pedoman Diagnosis Gangguan Jiwa di Indonesia III.

Hasil penelitian tentang hubungan nilai kortisol pagi hari pada subjek yang mengalami depresi dengan tidak depresi, serta hubungan kadar kortisol pada sore hari pada subjek yang yang mengalami depresi dengan tidak depresi dapat dilihat pada tabel 1 dan 2 .

Tabel 1. Perbandingan nilai kortisol serum pagi hari pada subjek yang depresi dan non depresi

\begin{tabular}{|c|c|c|c|c|c|}
\hline \multirow[t]{2}{*}{ Variabel } & \multicolumn{4}{|c|}{ Kortisol serum pagi $(\mu \mathrm{g} / \mathrm{dL})$} & \multirow[b]{2}{*}{$\mathbf{p}$} \\
\hline & $\mathrm{n}$ & Mean & SD & $\mathbf{t}$ & \\
\hline Depresi & 12 & 410,8 & 159.5 & 3,013 & 0,006 \\
\hline Non depresi & 13 & 251,2 & 101,4 & & \\
\hline
\end{tabular}

Dari tabel diatas dapat disimpulkan kadar kortisol pagi hari pada subjek yang mengalami depresi memiliki perbedaan yang bermakna dengan subyek yang tidak mengalami depresi. 
Tabel 2. Perbandingan nilai kortisol serum sore hari pada subyek yang depresi dan non depresi

\begin{tabular}{|c|c|c|c|c|c|}
\hline \multirow[t]{2}{*}{ Variabel } & \multicolumn{4}{|c|}{ Kortisol serum sore $(\mu \mathrm{g} / \mathrm{dL})$} & \multirow[b]{2}{*}{$\mathbf{p}$} \\
\hline & $\mathbf{n}$ & Mean & SD & $\mathbf{t}$ & \\
\hline Depresi & 12 & 144,1 & 85,6 & 1,234 & 0,230 \\
\hline Non depresi & 13 & 108,0 & 59,2 & & \\
\hline
\end{tabular}

Pada tabel diatas terlihat kadar kortisol sore pada subjek yang mengalami depresi tidak memiliki perbedaan yang bermakna dengan subyek yang tidak mengalami depresi.

Sedangkan hubungan antara nilai kortisol serum pagi hari pada subjek yang mengalami gangguan haid dan haid normal, serta hubungan antara nilai kortisol serum pagi hari pada subjek yang mengalami gangguan haid dan haid normal ada pada tabel 3,4 .

Tabel 3. Perbandingan nilai kortisol serum pagi hari pada subyek yang mengalami gangguan haid dan haid normal

\begin{tabular}{lccccc}
\hline \multirow{2}{*}{ Variabel } & \multicolumn{4}{c}{ Kortisol serum pagi $(\boldsymbol{\mu g} / \mathbf{d L})$} & \multirow{2}{*}{ p } \\
\cline { 2 - 5 } & $\mathbf{n}$ & Mean & SD & t & 0,701 \\
\hline Oligo-amenorea & 8 & 345,5 & 147,8 & 0,389 & 0,701 \\
Haid normal & 17 & 319,5 & 159,2 & & \\
\hline
\end{tabular}

Dari tabel 3 dapat dilihat kadar kortisol pagi hari pada subjek dengan gangguan haid tidak memiliki perbedaan yang bermakna dengan subjek yang haidnya normal.

Tabel 4. Perbandingan nilai kortisol serum sore hari pada subyek yang mengalami gangguan haid dan haid normal

\begin{tabular}{|c|c|c|c|c|c|}
\hline \multirow[t]{2}{*}{ Variabel } & \multicolumn{4}{|c|}{ Kortisol serum sore $(\mu \mathrm{g} / \mathrm{dL})$} & \multirow[b]{2}{*}{$\mathbf{p}$} \\
\hline & $\mathbf{n}$ & Mean & SD & $\mathbf{t}$ & \\
\hline Oligo-amenorea & 8 & 124,7 & 52,9 & 0,029 & 0,977 \\
\hline Haid normal & 17 & 125,6 & 83,3 & & \\
\hline
\end{tabular}

Dari tabel 4 dapat dilihat kadar kortisol sore hari pada subjek dengan gangguan haid tidak memiliki perbedaan yang bermakna dengan subjek yang haidnya normal. 


\section{HUBUNGAN ANTARA GANGGUAN HAID DENGAN DEPRESI}

Table 5. Hubungan antara gangguan haid dan depresi pada wanita penghuni LP se Sumatera Barat

\begin{tabular}{lccc}
\hline & \multirow{2}{*}{ Depresi } & \multicolumn{3}{c}{ Oligo-amenorea } & \\
& Ya & Tidak & Total \\
\hline Ya & 5 & 7 & 12 \\
Tidak & 3 & 10 & 13 \\
Total & 8 & 17 & 25 \\
\hline
\end{tabular}

Fisher Exact Test

Dari tabel 5, dapat dilihat tidak terdapat hubungan yang bermakna antara gangguan haid yang terjadi dengan depresi yang dialami subjek ( $\mathrm{P}$ dengan Fisher Exact Test = 0,209).

\section{PEMBAHASAN}

Selama penelitian ini berlangsung ada 53 orang narapidana wanita penghuni LP se Sumatera Barat,25 orang terkait kasus penyalahgunaan narkoba dan 3 orang berusia diatas 40 tahun, jadi yang bisa berpartisipasi hanya 25 orang. Dari subjek yang ikut penelitian ini 12 orang (48\%) mengalami gangguan depresi, hal ini sesuai dengan penelitian Affandi dan Pernol bahwa wanita yang sedang menjalani tahanan penjara, terpisah dari keluarga akan mengalami tekanan jiwa yang cukup berat seperti gangguan depresi.

Ditemukan perbedaan yang bermakna nilai kortisol pagi hari pada subjek yang mengalami depresi dibandingkan dengan subjek yang tidak depresi, sedangkan nilai kortisol pada sore hari tidak ada perbedaan yang bermakna antara subjek yang mengalami depresi dengan subjek yang tidak depresi. Hal ini dimungkinkan karena depresi yang sudah terjadi berlangsung kronik menyebabkan gangguan sistem umpan balik HPA-aksis, sehingga tidak terjadi penghambatan sekresi kortisol seperti pada orang normal. Sekresi kortisol saat bangun tidur pagi meningkat $30 \%-60 \%$ dan bisa lebih tinggi lagi pada individu yang mengalami distres kronik. Sedangkan sekresi kortisol pada sore hari mulai menurun sampai saat kembali tidur malam harinya. ${ }^{(7,10)}$

Young EA dan Veldhuis JD, pada tahun 2006, dalam penelitiannya menemukan terjadinya peningkatan ACTH dan kortisol pada wanita depresi dibandingkan wanita normal. ${ }^{(9)}$ Pada penelitian ini didapatkan subjek yang mengalami gangguan haid sejak masuk penjara 8 orang $(32 \%)$ dan kasus depresi 12 orang (48\%). Tidak terdapat hubungan yang bermakna antara ganguan haid yang terjadi dengan depresi yang dialami subjek penelitian. Kemungkinan hal ini terjadi karena dilihat pada tabel induk subjek yang tidak mengalami depresi dan mendapat gangguan haid, hasil nilai kortisolnya sangat tinggi sesudah masuk penjara. Peningkatan kortisol ini yang menyebabkan ganguan haid, seperti diterangkan oleh Corwin dkk bahwa 
akibat peningkatan kortisol menekan

GnRH dan menghambat pelepasan LH sehingga terjadi oligomenorea dan amenorea. ${ }^{(6)}$

\section{KESIMPULAN dan SARAN}

- Ada perbedaan bermakna nilai kortisol pagi hari pada subjek yang mengalami depresi bila dibandingkan dengan subjek yang tidak mengalami depresi.

- Tidak ada perbedaan bermakna nilai kortisol sore hari pada subjek yang mengalami depresi bila dibandingkan dengan subjek yang tidak mengalami depresi.

- Pada penelitian ini juga tidak ditemukan hubungan yang bermakna antara gangguan depresi yang dialami subjek penelitian dengan gangguan haid yang dialami oleh para wanita yang ada di LP wanita se-Sumatera Barat .

- Diperlukan penelitian lanjut untuk mendapatkan subjek dalam jumlah yang lebih besar lagi agar bisa membuktikan hubungan depresi dengan gangguan haid

\section{KEPUSTAKAAN}

1. Kaplan \& Sadock's: Mood Disorder, Dalam Synosis of Psychitry, Behavioral Sciences/ Clinical psychiatry, 10th Edition, Philadelphia, Lippincott Williams \& Wilkins, 2007, 527-578.

2. Affandi B. Gangguan Haid pada Remaja dan Dewasa. Balai
Penerbit FKUI, Jakarta, 1990; 17-28.

3. Pernol ML. Menstruation abnormalities and Complications. In Handbook of Obstetrics and Gynecology. $9^{\text {th }}$ ed, International Edition, Mc Graw Hill Inc, 1994; 23: 609626.

4. Burt, VK, Hendrick,VC,Mood Disorder in Women in Clinical Manual of Women's Mental Health, Arlington, American Psychiatric Publishing Inc. 2005; 151-159.

5. Canberra EJ. Hypothalamic Amenorrhea and Infertility. 2003; Diakses dari http://www.shadygrovefertility. com.

6. Corwin JE. Stress, Dalam Buku Saku Patofisiologi. EGC; Jakarta, 2001; 230-238.

7. Tyrell JB, Findling JW, Aaron CD. Glucocorticoids and Adrenal Androgens. In Basic \& Clinical Endocrinology, $5^{\text {th }}$ Edition, Appleton and Lange, USA, 1997; 317-345.

8. Charmandari E, Tsigos C, Chrousos G. Endocrinology of The Stress Response. Annu. Rev. Physiol, 2005; 67: 259284.

9. Young EA, Veldhuis JD. Disordered Adrenocorticotropin Secretion in Women with Major Depression. J Clin Endocrinol Metab, 2006; 91:1924-1928. 
10. Moore B. Cortisol, Serotonin and Depresion. The British Journal of Psychiatry, 2002; 181: 348 .

11. Baziad A. Gangguan Haid. Dalam Endokrinologi Ginekologi, Edisi kedua, Penerbit Media Aesculapius Fakultas Kedokteran Universitas Indonesia, Jakarta, 2003; 25-34.
12. Hunter TM, Heiman DL. Amenorrhea: Evaluation and Treatment. Am Fam Physician, 2006; 73: 1374-82,1387.

13. Schillings WJ, Clamrock HM. Amenorrhea. In Novak's Gynecology. $13^{\text {th }}$ ed. Philadelphia Lippincott Williams \& Wilkins, 2002; 843-869. 